\title{
PENETAPAN HARGA POKOK PRODUKSI DENGAN METODE FULL COSTING SEBAGAI DASAR PENENTUAN HARGA JUAL KAIN TENUN SONGKET MELAYU
}

\author{
Dariana \\ Sekolah Tinggi Ilmu Ekonomi (STIE) Syariah Bengkalis, Riau, Indonesia \\ dariana.bengkalis72@gmail.com \\ https://doi.org/10.46367/jas.v4i2.247 \\ Received: Oct 21, 2020 Revised: Nov 23, 2020 Accepted: Dec 11, 2020 Published: Dec 16, 2020
}

\begin{abstract}
Songket Melayu weaving craftsmen in determining the cost of production as the basis for determining the selling price are still inaccurate because they are based on estimates and have not classified costs in the calculation of the cost of production. This study aims to assist in determining the cost of goods manufactured as a basis for determining the selling price using the full costing method. This research is descriptive qualitative research. The results of this study indicate the difference in the cost of production between the weaving craftsmen's calculations with the full costing method. The result of the calculation of the cost of production according to the weaving craftsman is IDR 483,333.33 per piece, while the full costing method is IDR 528,833.00 per piece. The difference in production costs is IDR 45,500.00 lower than using the full costing method. The determination of the selling price of the product is based on the cost of goods sold per piece of woven fabric plus the desired profit of the company of $35 \%$ in order to cover the production costs that have been incurred. The result of the calculation of the selling price according to the weaving craftsman is IDR 113,925.00 per piece lower than using the full costing method.
\end{abstract}

Keywords: Cost of Goods Sold, Full Costing, Malay Songket Weaving.

\begin{abstract}
ABSTRAK
Pengrajin tenun Songket Melayu dalam menentukan harga pokok produksi sebagai dasar penentuan harga jual masih kurang tepat karena berdasarkan taksiran dan belum mengklasifikasikan biaya dalam perhitungan harga pokok produksinya. Penelitian ini bertujuan untuk membantu dalam penetapan harga pokok produksi sebagai dasar penentuan harga jual dengan menggunakan metode full costing. Penelitian ini termasuk penelitian deskriptif kualititatif. Hasil penelitian ini menunjukkan perbedaan harga pokok produksi antara perhitungan pengrajin tenun dengan metode full costing. Hasil perhitungan harga pokok produksi menurut pengrajin tenun sebesar Rp 483.333,33 per helai sedangkan dengan metode full costing Rp 528.833,00 per helai. Selisih biaya produksi lebih rendah $\mathrm{Rp}$ 45.500,00 dibanding dengan menggunakan metode full costing. Penentuan harga jual produk berdasarkan harga pokok penjualan per helai kain tenun ditambah dengan laba yang diinginkan perusahaan sebesar 35\% dengan tujuan dapat menutup biaya produksi yang sudah dikeluarkan. Hasil perhitungan
\end{abstract}


harga jual menurut pengrajin tenun lebih rendah $\mathrm{Rp} 113.925,00$ per helai dibanding dengan menggunakan metode full costing.

Kata Kunci: Harga Pokok Produksi, Full Costing, Tenun Songket Melayu.

\section{PENDAHULUAN}

Perkembangan dunia usaha di Indonesia saat ini berkembang pesat dan membuat persaingan semakin meningkat. Proses industrialisasi masyarakat di Indonesia sangat beraneka ragam, baik dari sektor pertanian, kerajinan tangan, makanan, dan lain sebagainya. Banyak perusahaan yang bermunculan, mulai dari perusahaan kecil, menengah sampai perusahaan besar. Dalam menghadapi persaingan, perusahaan seharusnya mempunyai strategi dan metode yang tepat supaya dapat menghasilkan keuntungan yang tinggi dan produknya dapat tetap bersaing. Ketatnya persaingan bisnis ini menyebabkan perusahaan harus berhatihati dalam menentukan strategi dan metode, khususnya dalam menentukan metode penentuan harga jual, karena harga jual berdampak besar pada penjualan perusahaan yang nantinya akan memberikan keuntungan pada perusahaan. Menentukan harga jual suatu produk perusahaan juga perlu memperhatikan pesaing sekitar karena jika harga jual akan diberikan lebih tinggi dibandingkan pesaing, perusahaan tidak bisa menemukan pelanggan karena produknya mahal dipasaran.

Riau adalah salah satu Provinsi di Sumatera yang memiliki jumlah UMKM yang begitu besar dan tumbuh pesat bersamaan dengan sejumlah industri lainnya. UMKM tersebut meliputi industri kuliner (produk makanan), tekstil, mebel, kerajinan tenun, dan usaha kecil lainnya. Tenun di Riau sering dikenal dengan sebutan tenun songket melayu. Tenun songket melayu merupakan kain hasil kerajinan tangan yang dilakukan dengan melalui proses menenun benang yang diselingi dengan tenunan benang emas atau benang perak dengan ragam motif atau corak tenunan tertentu. Tidak semua daerah di Riau yang dijadikan sentra tenun songket melayu ini. Ia hanya terpusat di beberapa daerah saja, seperti Kota Pekanbaru, Siak, Pelalawan, Rokan Hulu, Rokan Hilir, dan Bengkalis.

Kabupaten Bengkalis merupakan salah satu Kabupaten di Provinsi Riau. Negeri dengan julukan negeri junjungan ini selain memiliki kekayaan alam yang melimpah, juga dikenal sebagai sentra tenun songket yang cukup besar dan cukup dikenal serta diminati oleh orang Riau, luar daerah, maupun mancanegara. Banyak masyarakat desa yang menggeluti pekerjaan sebagai pengrajin tenun ini, baik sebagai pekerjaan tetap maupun pekerjaan sampingan untuk menunjang kebutuhan rumah tangga. Dulunya, sentra tenun songket ini hanya berada di Kecamatan Bukit Batu, namun seiring perkembangan sampai sekarang ini telah tersebar di hampir seluruh daerah di Kabupaten Bengkalis.

Setiap pengrajin tenun memproduksi tenun dengan menggunakan Alat Tenun Bukan Mesin (ATBM). Produk yang dihasilkan yaitu kain tenun songket khas Riau. Kebanyakan usaha tenun songket ini adalah usaha perorangan, artinya memproduksi dan menjual sendiri hasil tenunannya. Jumlah pengrajin tenun di Kecamatan Bengkalis menurut data dari Dinas Koperasi dan Usaha Mikro Kecil Menengah Kabupaten Bengkalis pada tahun 2017 berjumlah 120 unit, tahun 2018 berjumlah 109 unit, sedangkan di tahun 2019 berjumlah 110 usaha tenun. Dari 
jumlah tersebut dibagi menjadi dua kategori yaitu usaha rumah tangga dan usaha mikro yang membuka dan menerima lapangan kerja.

Pengrajin tenun membutuhkan input atau faktor produksi untuk menghasilkan kain tenun. Input yang dibutuhkan dalam proses produksi berupa bahan baku dan tenaga kerja. Untuk memperoleh input tersebut diperlukan pengeluaran yaitu biaya bahan baku dan biaya tenaga kerja langsung. Biaya ini disebut dengan biaya produksi langsung.

Semua pengusaha baik besar maupun skala mikro, kecil, dan menengah, biasanya selalu berusaha meningkatkan pendapatan (laba) yang diperolehnya. Banyak cara akan ditempuh untuk mendapatkan pendapatan yang lebih besar. Salah satunya adalah dengan menekan biaya produksi, serta menstabilkan harga jual sesuai dengan biaya yang dikeluarkan.

Bagi pengrajin tenun sendiri, harga jual ini dinilai sangat menentukan pendapatan yang diterima oleh mereka disamping perlu memperhatikan biaya yang dikeluarkan untuk memproduksi sebuah kain tenun. Berdasarkan observasi di lapangan dengan menemui beberapa pengrajin tenun, penulis mendapati informasi bahwa harga jual kain tenun berkisar antara Rp 550.000,00 sampai dengan harga Rp 750.00,00 per helai. Harga ini dipatok berdasarkan jumlah biaya produksi yang dikeluarkan dan faktor lain seperti motif dan jenis kain tenun yang diproduksi.

Perusahaan yang memproduksi suatu barang memerlukan infomasi jumlah biaya yang dikeluarkan untuk menghasilkan produk. Biaya produksi seperti bahan baku, tenaga kerja dan overhead pabrik lainnya digunakan sebagai dasar untuk menghitung harga pokok produksi. Dengan persaingan usaha antar perusahaan yang menghasilkan produk sejenis, perusahaan harus mampu menghadapi tuntutan dan tantangan yang ada baik dari segi kuantitas maupun kualitasnya.

Oleh karena itu penghitungan harga pokok produksi merupakan alat ukur untuk menentukan harga pokok penjualan. Begitu juga dengan pelaku UMKM lainnya khususnya pada pengrajin tenun songket melayu harus benar-benar dapat menghitung biaya produksi yang dikeluarkan untuk menentukan harga jual. Kesalahan dalam penghitungan harga pokok produksi berpengaruh terhadap harga jual. UMKM dituntut lebih efektif dan efisien dalam menjalankan usahanya agar produk yang dihasilkan mempunyai kualitas yang bagus sehingga memiliki daya saing dengan para kompetitor antar UMKM. Selain kualitas penentuan harga jual harus dengan harga yang wajar tidak terlalu rendah dan juga tidak terlalu tinggi. Apabila harga terlalu tinggi perusahaan kesulitan bersaing sebaliknya jika harga teralalu rendah maka keuntungan yang diharapkan kurang maksimal. Untuk itu penentuan harga jual harus dilakukan dengan penghitungan yang akurat dan tepat dalam menghasilkan produk.

Menurut pra penelitian yang dilakukan peneliti selama ini perhitungan harga pokok produksi maupun harga pokok penjualan berdasarkan taksiran atau perkiraan saja. Baik secara administratif maupun pembukuannya UMKM pengelola usaha kurang memperhatikan. Menghindari terjadinya kesalahan dalam penentuan harga pokok produksi diperlukan suatu metode yang tepat. Metode yang sebaiknya digunakan adalah menggunakan metode biaya penuh (full costing). Menurut Bustami and Nurlela (2006) full ccosting digunakan untuk meningkatkan akurasi. Pengumpulan biaya produksi dilakukan dengan menggunakan metode harga pokok proses karena ada atau tidak suatu pesanan 
perusahaan selalu memproduksi kain tenun. Metode ini menghitung biaya tetap karena dianggap melekat pada harga pokok persediaan barang dalam proses maupun produk jadi yang belum terjual dan dianggap sebagai harga pokok penjualan apabila produk yang dijual habis sehingga perusahaan memperoleh biaya tepat dan akurat serta dapat menetapkan harga jual yang bersaing (Srikamilah 2017). Dalam menentukan harga pokok produksi, perusahaan masih menggunakan taksiran belum memasukkan semua unsur biaya khususnya biaya overhead pabrik baik biaya overhead pabrik tetap maupun variabel, biaya pemeliharaan mesin dan peralatan maupun biaya penyusutannya. Metode ini menghitung biaya tetap karena dianggap melekat pada harga pokok persediaan barang dalam proses maupun produk jadi yang belum terjual dan dianggap sebagai harga pokok penjualan apabila produk yang dijual habis sehingga perusahaan memperoleh biaya tepat dan akurat serta dapat menetapkan harga jual yang bersaing.

Setiadi et al. (2014), meneliti tentang pengklasifikasian biaya yang diterapkan oleh CV. Minahasa Mantap Perkasa dalam perhitungan HPP serta perhitungan HPP Perusahaan dalam penentuan harga jual dan mengetahui perhitungan/penentuan harga jual produk yang diterapkan. Pengumpulan HPP yang digunakan adalah metode harga pokok proses (process cost method), sedangkan metode penentuan harga pokok produksi menggunakan pendekatan full costing. Dalam menentukan harga jual produk, perusahaan menggunakan metode cost plus pricing. Pengumpulan biaya produksi dilakukan dengan metode harga pokok proses dengan pendekatan full costing, tujuannya untuk memenuhi persediaan digudang, dan jumlahnya sama dari waktu ke waktu. Pentingnya perhitungan harga pokok produksi dengan metode full costing guna menentukan harga jual, maka penelitian ini bertujuan untuk membantu dalam penetapan harga pokok produksi sebagai dasar penentuan harga jual kain tenun songket melayu dengan menggunakan metode full costing.

\section{TELAAH LITERATUR}

\section{Biaya Produksi}

Biaya produksi menurut Sukirno $(2013,208)$, adalah semua pengeluaran yang dilakukan oleh perusahaan untuk memperoleh faktor-faktor produksi dan bahan-bahan mentah yang akan digunakan untuk menciptakan barang-barang yang diproduksikan perusahaan tersebut. Sedangkan menurut Ardiyose (2013) biaya produksi adalah biaya yang terjadi untuk menghasilkan suatu produk atas jasa, biaya-biaya ini dapat diklasifikasikan dalam tiga jenis yaitu bahan langsung, tenaga kerja langsung, dan overhead pabrik.

Sunarto (2004, 175) menyatakan faktor yang memiliki kepastian yang relatif tinggi yang berpengaruh terhadap penentuan harga jual adalah biaya. Oleh karena itu, untuk memperoleh dan mengolah bahan-bahan menjadi produk jadi dalam kegiatan proses produksi diperlukan dana atau biaya-biaya, maka untuk pengeluaran biaya-biaya tersebut biasanya perusahaan memperhitungkannya dalam penetapan harga jual produk. Untuk itu perusahaan berusaha menekan atau memperkecil pengeluaran biaya, khususnya yang berkaitan dengan kegiatan proses produksi, baik mengenai biaya perolehan bahan baku, biaya yang 
dikeluarkan untuk bahan pembantu atau penolong, biaya tenaga kerja, penyusutan peralatan, pemeliharaan dan sebagainya.

Untuk melakukan proses produksi, setiap perusahaan membutuhkan biaya produksi yang terdiri dari biaya bahan baku, biaya tenaga kerja langsung, dan biaya overhead pabrik (Mursyidi 2010,14). Sedangkan metode penentuan biaya produksi adalah cara memperhitungkan unsur-unsur biaya ke dalam biaya produksi. Dalam memperhitungkan unsur-unsur biaya produksi, terdapat dua pendekatan (Mursyidi 2010, 24) yaitu: (1) Full costing, merupakan metode penentuan biaya produksi yang memperhitungkan semua unsur biaya produksi. Biaya produksi menurut metode full costing terdiri dari unsur biaya produksi sebagai berikut:

$\begin{array}{ll}\text { Biaya Bahan Baku } & \text { xxx } \\ \text { Biaya Overhead Pabrik Variabel } & \text { xxx } \\ \text { Biaya Overhead Pabrik Tetap } & \underline{\mathbf{x x}} \\ \text { Biaya Produksi } & \mathbf{x x x}\end{array}$

(2) Variabel costing, merupakan metode penentuan biaya produksi yang hanya memperhitungkan biaya produksi yang berperilaku variabel ke dalam biaya produksi. Biaya produksi menurut metode variabel costing terdiri:

$\begin{array}{ll}\text { Biaya Bahan Baku } & \text { xxx } \\ \text { Biaya Tenaga Kerja Langsung } & \text { xxx } \\ \text { Biaya Overhead Pabrik Variabel } & \underline{\mathbf{x x}} \\ \text { Biaya Produksi } & \mathbf{x x x}\end{array}$

\section{Harga Pokok Produksi}

Menurut Samsul (2013), harga pokok produksi adalah biaya untuk menghasilkan produk pada perusahaan manufaktur. Bustami $(2010,40)$ penentuan harga pokok adalah bagaimana memperhitungkan biaya kepada suatu produk atau pesanan atau jasa, yang dapat dilakukan dengan cara memasukkan seluruh biaya produksi atau hanya memasukkan unsur biaya produksi variabel saja. Menurut Hansen and Mowen (2004, 48) dalam (Batubara 2013) bahwa harga pokok produksi adalah mewakili jumlah biaya barang yang diselesaikan pada periode tertentu. Menurut Setiadi (2014) harga pokok adalah sejumlah nilai aktiva (aset) tetapi apabila selama tahun berjalan aktiva tersebut dimanfaatkan untuk membantu memperoleh penghasilan, aktiva tersebut harus dikonversikan ke beban.

Mulyadi $(2014,65)$ dalam perusahaan yang berproduksi massa, informasi harga pokok produksi yang dihitung untuk jangka waktu tertentu bermanfaat bagi manajemen untuk: (a) menentukan harga jual produk; (b) memantau realisasi biaya produksi; (c) menghitung laba atau rugi periodik (d) menentukan harga pokok persediaan produk jadi dan produk dalam proses yang disajikan dalam neraca.

\section{Harga Jual}

Kotler and Amstrong $(2008,27)$ menjelaskan bahwa harga adalah nilai yang dipertukarkan konsumen untuk suatu manfaat atas pengonsumsian, penggunaan, atau kepemilikan barang atau jasa. Artinya, harga adalah jumlah nilai yang harus dibayar konsumen demi memiliki atau mendapatkan keuntungan dari sebuah produk barang atau jasa. Sedangkan menurut Stanton $(2002,178)$ harga 
adalah sejumlah uang yang dibutuhkan atau dikeluarkan untuk memperoleh beberapa kombinasi sebuah produk atau pelayanan yang menyertainya.

Menurut Kotler and Amstrong $(2008,84)$ dalam menetapkan harga dari suatu produk, terdapat faktor-faktor yang menentukan kebijakan penetapan harga, yaitu: (a) memilih tujuan penetapan harga, (b) menentukan permintaan, (c) memperkirakan biaya, (d) menganalisa biaya, harga, dan tawaran pesaing, (e) memilih metode penetapan harga, dan (f) memilih harga akhir. Selain terdapat faktor-faktor yang menentukan kebijakan penetapan harga di atas, juga terdapat faktor yang mempengaruhi tingkat harga. Menurut Swastha (2005, 242), tingkat harga dipengaruhi oleh beberapa faktor, yaitu: (a) keadaan perekonomian, (b) penawaran dan permintaan, (c) elastisitas permintaan, (d) persaingan, (e) biaya, (f) tujuan perusahaan, dan $(\mathrm{g})$ pengawasan pemerintah.

Tjiptono (1997) mengemukakan bahwa penetapan harga jual mempunyai beberapa tujuan, yaitu: (a) Tujuan berorientasi pada laba. Asumsi teori ekonomi klasik menyatakan bahwa setiap perusahaan selalu memilih harga jual yang dapat menghasilkan harga jual paling tinggi. (b) Tujuan berorientasi pada volume. Harga jual ditetapkan sedemikian rupa agar dapat mencapai volume penjualan (dalam ton, $\mathrm{kg}$, dan lain-lain), nilai penjualan ( $\mathrm{Rp}$ ), atau pangsa pasar (absolute maupun relatif). (c) Tujuan berorientasi pada citra. Perusahaan dapat menetapkan harga jual tinggi untuk membentuk atau mempertahankan citra prestisius. Harga rendah dapat digunakan untuk membentuk citra nilai tertentu. (d) Tujuan stabilisasi harga jual. Tujuan stabilisasi dilakukan dengan jalan menetapkan harga untuk mempertahankan hubungan yang stabil antara harga suatu perusahaan dan harga pemimpin industri. (e) Tujuan-tujuan lainnya. Harga dapat pula ditetapkan dengan tujuan mencegah masuknya pesaing, mempertahankan loyalitas pelanggan, mendukung penjualan ulang, atau menghindari campur tangan pemerintah.

\section{Tenun Songket}

Berbagai pengertian telah banyak dikemukakan oleh para ahli mengenai pertenunan. Pengertian ini secara umum merujuk kepada pengertian yang sama, yaitu memintal bahan-bahan tertentu yang dapat dibuat menjadi benang yang kemudian dibuat kain atau sarung dengan menggunakan teknik-teknik dan alat tertentu. Widati and Poerwadarminta $(2002,115)$ mengartikan tenun sebagai hasil kerajinan berupa kain dari bahan yang dibuat benang (kapas, sutra dan sebagainya) dengan cara memasukkan bahan secara melintang pada lusi. Alat yang digunakan untuk menenun kain secara umum adalah gedokan dan ATBM ( Alat Tenun Bukan Mesin). Gedokan adalah alat tenun yang masih sangat sederhana yang difungsikan secara tradisional, akan menghasilkan kain selebar 55 $\mathrm{cm}$. Sehingga untuk membuat kain sarung dengan panjang $110 \mathrm{~cm}$ dengan panjang dua meter dibutuhkan lebih banyak bahan dan waktu penyelesaiannya. ATBM (Alat Tenun Bukan Mesin) adalah alat tenun dengan menggunakan alat yang lebih tertata yang terbuat dari kayu dan dikerjakan secara manual. Walaupun masih tergolong tradisional, namun lebih baik dari gedokan. 


\section{METODOLOGI PENELITIAN}

Penelitian ini dilaksanakan pada di UMKM home industri tenun tradisional yang berlokasi di jalan Utama Dusun Mekar RT 005 RW 003 Desa Senderak Kecamatan Bengkalis Kabupaten Bengkalis tahun 2020. Teknik pengumpulan data yang digunakan yaitu: wawancara, dokumentasi dan studi pustaka. Sumber data yang digunakan adalah data primer dimana data langsung diberikan oleh sumber data yaitu pelaku home industri tenun tradisional, data diperoleh melalui keterangan-keterangan dari sumbernya langsung dan melalui pengamatan serta wawancara. Teknik analisis data dalam penelitian ini adalah deskriptif kualitatif .

\section{HASIL PENELITIAN DAN PEMBAHASAN}

\section{Harga Pokok Produksi}

Tabel 1 Pembelian Bahan Baku Benang Pakang dan Benang Rentang Bulan Agustus 2020

\begin{tabular}{ccccc}
\hline No & Tanggal & $\begin{array}{c}\text { Jumlah } \\
(\text { Gulung) }\end{array}$ & $\begin{array}{c}\text { Harga/Gulung } \\
(\mathbf{R p})\end{array}$ & $\begin{array}{c}\text { Pembelian } \\
(\mathbf{R p})\end{array}$ \\
\hline 1 & 1 Agust 2020 & 32 & $15.000,00$ & $480,000,00$ \\
2 & 4 Agust 2020 & 16 & $15.000,00$ & $240.000,00$ \\
3 & 10 Agust 2020 & 24 & $15.000,00$ & $360.000,00$ \\
4 & 19 Agust 2020 & 24 & $15.000,00$ & $360,000,00$ \\
5 & 26 Agust 2020 & 24 & $15.000,00$ & $360.000,00$ \\
\hline & Jumlah & $\mathbf{1 2 0}$ & & $\mathbf{1 . 8 0 0 . 0 0 0 , 0 0}$ \\
\hline
\end{tabular}

Sumber: Pengrajin Tenun

Tabel 2 Pembelian Bahan Baku Benang Mas Bulan Agustus 2020

\begin{tabular}{ccccc}
\hline No & Tanggal & $\begin{array}{c}\text { Jumlah } \\
(\text { Gulung) }\end{array}$ & $\begin{array}{c}\text { Harga/Gulung } \\
(\mathbf{R p})\end{array}$ & $\begin{array}{c}\text { Pembelian } \\
(\mathbf{R p})\end{array}$ \\
\hline 1 & 1 Agust 2020 & 12 & $30.000,00$ & $360,000,00$ \\
2 & 4 Agust 2020 & 6 & $30.000,00$ & $180.000,00$ \\
3 & 10 Agust 2020 & 12 & $30.000,00$ & $360.000,00$ \\
4 & 19 Agust 2020 & 9 & $30.000,00$ & $270,000,00$ \\
5 & 26 Agust 2020 & 6 & $30.000,00$ & $180.000,00$ \\
\hline & Jumlah & $\mathbf{4 5}$ & & $\mathbf{1 . 3 5 0 . 0 0 0 , 0 0}$ \\
\hline
\end{tabular}

Sumber: Pengrajin Tenun

Dalam memproduksi tenun songket melayu di home industri tenun tradisional bahan baku yang digunakan adalah benang, yaitu benang untuk pakang, benang untuk rentang dan benang mas. Dari data pembelian bahan baku pada Tabel 1 dan Tabel 2, menurut pengrajin tenun pembelian bahan baku untuk pembuatan 1 helai kain tenun songket melayu memerlukan benang pakang sebanyak 4 gulung, benang rentang sebanyak 4 gulung dan benang mas 3 gulung. 
Tabel 3 Biaya Tenaga Kerja

\begin{tabular}{cccc}
\hline Bagian & $\begin{array}{c}\text { Jumlah Kain } \\
\text { Di Tenun }\end{array}$ & $\begin{array}{c}\text { Upah/Helai } \\
(\mathbf{R p})\end{array}$ & $\begin{array}{c}\text { Jumlah Biaya } \\
\text { Tenaga Kerja (Rp) }\end{array}$ \\
\hline Penenun 1 & 5 & $250.000,00$ & $1.250 .000,00$ \\
Penenun 2 & 5 & $250.000,00$ & $1.250 .000,00$ \\
Penenun 3 & 5 & $250.000,00$ & $1.250 .000,00$ \\
\hline Jumlah & $\mathbf{1 5}$ & & $\mathbf{3 . 7 5 0 . 0 0 0 , 0 0}$ \\
Sumber: Pengrajin Tenun & &
\end{tabular}

Untuk menenun kain tenun songket melayu di home industri tenun tradisional mempunyai 3 orang karyawan (lihat Tabel 3). Karyawan dibayar berdasarkan banyaknya kain tenun yang di hasilkan, dimana proses menenun sehelai kain memerlukan waktu 5 atau 6 hari, dimana pengrajin tenun ini berkerja tidak full time, atau bekerja sampingan saja.

Tabel 4 Biaya Bahan Penolong

\begin{tabular}{ccc}
\hline No & Jenis Biaya & $\begin{array}{c}\text { Jumlah Biaya } \\
\text { Overhead }(\mathbf{R p})\end{array}$ \\
\hline 1 & Biaya Ngelos Benang & $175.000,00$ \\
2 & Biaya Mengani/Mengulung Benang & $175.000,00$ \\
\hline \multicolumn{2}{c}{ Jumlah } & $\mathbf{3 5 0 . 0 0 0 , 0 0}$ \\
\hline Sumber: Pengrajin Tenun
\end{tabular}

\section{Perhitungan Harga Pokok Produksi Menurut Pengrajin Tenun}

Pengrajin tenun tradisional dalam menghitung harga pokok produksi dengan membagi jumlah produk yang dihasilkan. Penentuan harga pokok produksi yang dilakukan pengrajin tenun masih sangat sederhana. Biaya-biaya yang diakui pada perhitungan harga pokok produksi adalah biaya bahan baku, biaya tenaga kerja, dan biaya bahan penolong. Pengrajin tenun tradisional tidak menghitung biaya overhead pabrik secara lengkap (lihat Tabel 4), seperti biaya pemeliharaan mesin, biaya listrik dan biaya penyusutan mesin tidak diakui oleh pengrajin ketika menghitung harga pokok produksi.

Berdasarkan biaya-biaya yang telah ditentukan diatas, maka dapat dihitung harga pokok produksi menurut penghitungan pengrajin tenun. dengan menggunakan data dalam 1 bulan penenun dapat menghasilkan 5 helai kain songket ( 1 helai tenun memerlukan waktu 5 atau 6 hari proses penyelesaiannya), karena jumlah penenun 3 orang maka jumlah kain yang di hasilkan sebanyak 15 helai kain tenun lengkap dengan selendang motif penuh (kualitas menengah). Berdasarkan Tabel 5 harga pokok produksi dengan menggunakan perhitungan pengrajin tenun yaitu sebesar Rp 483.333,33 per helai kain tenun. 
Tabel 5 Perhitungan Harga Pokok Produksi Dengan Perhitungan Pengrajin Tenun Agustus 2020

\begin{tabular}{lc}
\hline \multicolumn{1}{c}{ Jenis Biaya } & Total Biaya (Rp) \\
\hline Biaya Bahan Baku & $3.150 .000,00$ \\
Biaya Tenaga Kerja Langsung & $3.750 .000,00$ \\
Biaya Bahan Penolong & $350.000,00$ \\
Jumlah Harga Pokok Produksi & $7.250 .000,00$ \\
Jumlah Produksi Yang Dihasilkan & $15 \mathrm{Helai}$ \\
Harga Pokok Produksi Per Helai & $\mathbf{4 8 3 . 3 3 3 , 3 3}$ \\
\hline Sumber: Data olahan
\end{tabular}

Perhitungan Harga Pokok Produksi Menurut Metode Full Costing

Perhitungan harga pokok produksi pada penelitian ini menggunakan metode full costing dengan menjumlahkan semua unsur-unsur biaya dalam proses produksi. Berdasarkan biaya-biaya tersebut perhitungan harga pokok produksi menggunakan metode full costing dapat dilihat pada Tabel 6.

Tabel 6 Biaya Overhead

\begin{tabular}{clc}
\hline No & \multicolumn{1}{c}{ Jenis Biaya } & $\begin{array}{c}\text { Jumlah Biaya } \\
\text { Overhead }(\mathbf{R p})\end{array}$ \\
\hline 1 & Listrik & $120.000,00$ \\
2 & Biaya penyusutan Mesin ATBM & $112.500,00$ \\
3 & Biaya pemeliharaan mesin & $150.000,00$ \\
\hline \multicolumn{2}{c}{ Jumlah } & $\mathbf{3 8 2 . 5 0 0 , 0 0}$ \\
\hline \multicolumn{2}{l}{ Sumber: Pengrajin Tenun }
\end{tabular}

Biaya overhead pabrik yang diakui pada saat menghitung harga pokok produksi hanya biaya overhead pabrik. Adapun yang termasuk dalam biaya overhead pabrik dalam pembuatan kain tenun songket ini yaitu biaya listrik, biaya ngelos benang, biaya mengani (menggulung) benang dan biaya penyusutan mesin ATBM. Sedangkan BOP tetap termasuk biaya periodik, mesin ATBM dianggap sebagai biaya periode (period cost) yang langsung dibebankan kepada rugi laba periode terjadinya dan tidak diperlakukan sebagai biaya produksi. Pada Tabel 6 biaya penyusutan mesin di hitung dengan metode Garis Lurus dengan rumus, Penyusutan Harga Perolehan - Nilai Residu : taksiran umur ekonomi. Penyusutan mesin ATBM $=\operatorname{Rp~5.000.000,00~}-\operatorname{Rp} 500.000,00: 10$ tahun $=\operatorname{Rp} 450.000,00$ per tahun, untuk per bulannya adalah Rp 37.500,00. Jumlah mesin tenun ATBM ada 3 unit (3 unit $x \operatorname{Rp~37.500/bulan~}=\operatorname{Rp~112.500,00).~}$ 
Tabel 7 Perhitungan Harga Pokok Produksi Dengan Metode Full Costing Agustus 2020

\begin{tabular}{lrr}
\hline \multicolumn{1}{c}{ Jenis Biaya } & \multicolumn{1}{c}{ Total Biaya (Rp) } \\
\hline Biaya Bahan Baku & & $3.150 .000,00$ \\
Biaya Tenaga Kerja Langsung & & $3.750 .000,00$ \\
Biaya Bahan Penolong Variabel & & \\
$\quad \quad$ Biaya Ngelos Benang & $175.000,00$ & \\
$\quad$ Biaya Mengani Benang & $175.000,00$ & \\
Biaya Overhead Pabrik & & \\
Biaya Listrik & $120.000,00$ & \\
Depresiasi ATBM & $112.500,00$ & \\
Pemeliharaan ATBM & $150.000,00$ & \\
Jumlah Biaya Overhead Pabrik & $732.500,00$ & \\
Total Biaya Produksi & & $\mathbf{7 . 6 3 2 . 5 0 0 , 0 0}$ \\
Jumlah Produk yang Dihasilkan/bln & & $\mathbf{5 0 8 . 8 3 3 , 0 0}$ \\
Harga Pokok Produksi Per helai & & \\
Sumber: Data olahan & &
\end{tabular}

Tabel 7 menunjukkan bahwa harga pokok produksi yang dihasilkan dengan menggunakan metode full costing pada pengrajin tenun songket melayu yaitu sebesar Rp 508.833,00 per helai kain tenun.

\section{Harga Pokok Penjualan Untuk Menentukan Harga Jual}

Perhitungan harga pokok penjualan kain tenun songket melayu menurut pengrajin tenun, harga jual per helai kain sebesar Rp. 600.000,00 (kain tenun dan selendang) penentuan harga tersebut berdasarkan perkiraan saja dengan kata lain menganggap dengan harga Rp. 600.000,00 sudah memperoleh laba.

Tabel 8 Perhitungan Harga Pokok Penjualan Menggunakan Metode Full Costing

\begin{tabular}{lr}
\hline \multicolumn{1}{c}{ Keterangan } & Total Biaya (Rp) \\
\hline Harga Pokok Produksi & $7.632 .500,00$ \\
Biaya Pemasaran (Non Produksi) & 300.000 .00 \\
Total & $7.932 .500,00$ \\
Jumlah Produksi (Helai Tenun)/Bulan & 15 helai \\
Biaya Per (Helai Tenun) & $\mathbf{5 2 8 . 8 3 3 , 0 0}$ \\
\hline
\end{tabular}

Sumber: Data olahan

Berdasarkan Tabel 8 diketahui bahwa harga pokok penjualan per helai

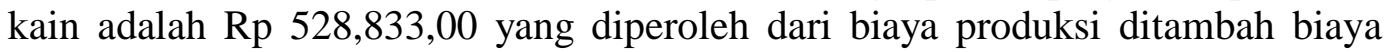
non produksi (biaya pemasaran) dibagi dengan jumlah produksi tenun dalam 1 bulan yaitu 15 helai kain tenun. Harga tersebut menjadi dasar untuk menjual kain tenun per helai agar tidak menjual kain tenun dibawah harga tersebut. Laba yang diharapkan oleh pengrajin tenun adalah sebesar $35 \%$ dari harga pokok penjualan. Berdasarkan perhitungan diatas, untuk menentukan harga jual dapat ditentukan sebagai berikut:

Harga jual/helai= Harga pokok penjualan + Persentase laba yang diinginkan $=\operatorname{Rp} 528,833,00+(\operatorname{Rp} 528.833,00 \times 35 \%)$ 


$$
\begin{aligned}
& =\operatorname{Rp} 528,833,00+\operatorname{Rp} 185.091,66 \\
& =\operatorname{Rp} 713.924,66 \\
& =\operatorname{Rp} 713.925,00 \text { (pembulatan) }
\end{aligned}
$$

Tabel 9 Perbandingan Harga Pokok Produksi dan Harga Jual menurut Pengrajin Tenun dan Metode Full Costing

\begin{tabular}{l|c|c|}
\hline \multicolumn{1}{c|}{ Keterangan } & $\begin{array}{c}\text { Harga Pokok Produksi } \\
(\mathbf{R p})\end{array}$ & $\begin{array}{c}\text { Harga Jual } \\
\text { (Rp) }\end{array}$ \\
\hline Menurut Pengrajin Tenun & $483.333,33$ & $600.000,00$ \\
\hline Metode Full Costing & $528.833,00$ & $713.925,00$ \\
\hline Selisih harga & $\mathbf{4 5 . 5 0 0 , 0 0}$ & $\mathbf{1 1 3 . 9 2 5 , 0 0}$ \\
\hline
\end{tabular}

Sumber : Data olahan

Berdasarkan Tabel 9 dapat diketahui adanya perbedaan harga pokok produksi antara perhitungan yang dilakukan antara pengrajin tenun dan metode full costing. Selisih biaya produksi sebesar Rp 45.500,00 per helai kain tenun. Pada perhitungan harga pokok produksi yang menggunakan metode full costing lebih tinggi karena semua biaya dirinci secara detil mulai dari perhitungan biaya bahan baku, biaya tenaga kerja langsung, biaya bahan penolong maupun biaya overhead pabrik. Sedangkan pengrajin tenun hanya menghitung biaya bahan baku, tenaga kerja langsung dan biaya bahan penolong, sehingga perhitungan harga pokok produksinya lebih kecil dibanding dengan metode full costing. Penentuan harga jual per helai tenun menurut pengrajin lebih rendah $\mathrm{Rp}$ 113.925,00 dari perhitungan harga jual dengan menggunakan metode full costing. Karena pada metode full costing ini perhitungan semua unsur biaya dimasukkan dalam perhitungan harga pokok penjualan baik biaya produksi maupun non produksi.

\section{KESIMPULAN}

Dalam menentukan harga pokok produksi antara perhitungan pengrajin tenun masih menggunakan taksiran belum memasukkan semua unsur biaya khususnya biaya overhead pabrik. Hasil perhitungan harga pokok produksi menurut pengrajin tenun lebih rendah $\mathrm{Rp}$ 45.500,00 dibanding dengan menggunakan metode full costing. Penentuan harga jual produk berdasarkan harga pokok penjualan per helai kain tenun ditambah dengan laba yang diinginkan perusahaan sebesar 35\% dengan tujuan dapat menutup biaya produksi yang sudah dikeluarkan. Hasil perhitungan harga jual menurut pengrajin tenun lebih rendah Rp 113.925,00 dibanding dengan menggunakan metode full costing. Hasil perbandingan perhitungan harga pokok produksi dengan metode full costing menghasilkan harga pokok per helai kain tenun lebih tinggi di bandingkan dengan perhitungan pengrajin tenun, hal ini dikarenakan dalam perhitungan metode full costing memasukkan semua biaya baik yang bersifat variable maupun tetap.

Untuk perbaikan ke depan dalam menghasilkan harga pokok produksi maupun menentukan harga jual sebaiknya pengrajin tenun/pelaku usaha lebih detil dalam menggolongkan biaya-biaya produksi baik tetap maupun variabel. Metode full costing sebaiknya digunakan karena metode ini lebih akurat. Sebaiknya pelaku home industri tenun songket melayu menerapkan pencatatan 
akuntansi baik keuangan maupun biaya meskipun dengan cara sederhana sehingga bisa terkontrol dan dapat mermberikan informasi perkembangan usahanya.

\section{DAFTAR PUSTAKA}

Ahmad, Kamaruddin. 2005. Akuntansi Manajemen. Jakarta: Raja Grafindo Persada.

Ardiyose. 2013. Kamus Besar Akuntansi. Jakarta: Citra Harta Prima.

Batubara, Helmina. 2013. "Penentuan Harga Pokok Produksi Berdasarkan Metode Full Costing Pada Pembuatan Etalase Kaca Dan Alumunium Di UD. Istana Alumunium Manado". Jurnal EMBA: Jurnal Riset Ekonomi, Manajemen, Bisnis Dan Akuntansi 1 (3): 217-224.

Bungin, Burhan. 2005. Metode Penelitian Kuantitatif. Jakarta: Prenada Media.

Bustami, Bastian and Nurlela. 2010. Akuntansi Biaya. Yogyakarta: Graha Ilmu.

Ghozali, Imam. 2005. Aplikasi Analisis Multivariate dengan SPSS. Semarang: Badan Penerbit UNDIP.

Harmono. 2011. Manajemen Keuangan. Jakarta: Bumi Aksara.

Horngren, Charles T. 2006. Akuntansi Biaya, Terj. P.A. Lestari. Jakarta: Penerbit Erlangga.

Karim, Adiwarman. 2011. Ekonomi Mikro Islam. Jakarta: Raja Grafindo Persada.

Kotler, Philip and Kevin Lane Keller, 2006. Manajemen Pemasaran, Terj. Bambang Sarwiji. Jakarta: Indeks.

Kotler , Philip and Gary Amstrong. 2008. Prinsip-Prinsip Pemasaran, Edisi 12 Jilid 1. Jakarta: Erlangga.

Mariani, Putu Lina, Made Ary Meitriana, and Anjuman Zukhri. 2014. "Penerapan Metode Full Costing Sebagai Dasar Perhitungan HPP Dalam Menentukan Harga Jual Produk DUPA Pada UD. Ganesha". Jurnal Jurusan Pendidikan Ekonomi Undiksha 4 (1).

Mulyadi. 2001. Akuntansi Manajemen: Konsep, Manfaat, dan Rekayasa, Edisi Tiga. Jakarta : Salemba Empat.

Mulyadi. 2014. Akuntansi Biaya, Edisi Lima. Yogyakarta: UPP STIM YKPN.

Muri, Yusuf. 2005. Metode Penelitian Kuantitatif, Kualitatif \& Penelitian Gabungan. Jakarta: Prenada Media.

Mursyidi. 2010. Akuntansi Biaya. Bandung: PT Refika Aditama.

Primyastanto, Istikharoh dkk. 2008. Potensi dan Peluang Bisnis. Jakarta: FEUI.

Priadana, Saludin. 2009. Metodologi Penelitian Ekonomi dan Bisnis. Yogyakarta: Graha Ilmu.

Rahardja, Pratama. 2010. Pengantar Ilmu Ekonomi (Mikroekonomi \& Makroekonomi). Jakarta: Lembaga Penerbit FEUI.

Rahman, Arif. 2010. Strategi Dahsyat Marketing Mix For Small Business: Cara Jitu Merontokkan Pesaing. Jakarta: Transmedia.

Samsul, Nienik H. 2013. "Perbandingan Harga Pokok Produksi Full Costing Dan Variable Costing Untuk Harga Jual CV. Pyramid". Jurnal EMBA: Jurnal Riset Ekonomi, Manajemen, Bisnis Dan Akuntansi 1 (3): 366-373.

Sari, Ni Putu Ayu Astiti, Made Arie Wahyuni, and Putu Eka Dianita Marvilianti Dewi. 2017. "Analisis Strategi Penentuan Harga Pokok Produksi Kain Songket Sutra Berdasarkan Metode Full Costing Pada Weaving Center 
Poni's Pengerajin Tenun Songket Sutra Di Desa Jinengdalem. Jurnal Ilmiah Mahasiswa Akuntansi 8 (2).

Setiadi, Pradana. David P.E. Saerang, and Treesje Runtu. 2014. "Perhitungan Harga Pokok Produksi dalam Penentuan Harga Jual pada CV. Minahasa Mantap Perkasa". Jurnal Berkala Ilmiah Efisiensi 14 (2): 70-81.

Siregar, Sofyan. 2013. Metode Penelitian Kuntitatif Dilengkapi Dengan Perbandingan Perhitungan Manual dan SPSS. Jakarta: Kencana.

Slamet, Achmad and Sumarli. 2002. "Pengaruh Perkiraan Biaya Produksi dan Laba yang Diinginkan Terhadap Harga Jual Pada Industri Kecil Genteng Pres, Dinamika: Jurnal Ekonomi dan Manajemen 11 (2): 45-56.

Soekartawi. 2002. Faktor-Faktor Produksi. Jakarta: Salemba Empat.

Srikalimah. 2017. "Penetapan Harga Pokok Produksi Tahu "Populer" Dengan

Metode Full Costing Sebagai Dasar Penentuan Harga Jual". Seminar Nasional Unikama.

Stanton, William J. 2002. Prinsip Pemasaran, Terj. Yohanes Lamarto. Jakarta: Erlangga.

Sugiyono. 2009. Metodologi Penelitian Bisnis (Pendekatan Kuantitatif, Kualitatif, dan $R \& D)$. Bandung: Alfabeta.

Sugiyono. 2017. Metodologi Penelitian Kuantitatif, Kualitatif, dan $R \& D$. Bandung: Alfabeta.

Sugiyono. 2006. Statistika Untuk Penelitian. Bandung: Alfabeta.

Suharyadi. Purwanto. 2007. Statistika: Untuk Ekonomi Keuangan Modern. Jakarta: Salemba Empat.

Sujarweni, Wiratna. 2015. Akuntansi Manajemen: Teori dan Aplikasi. Yogyakarta: Pustaka Baru.

Sukirno, Sadono. 2013. Mikro Ekonomi Teori Pengantar. Jakarta: PT Raja Grafindo Persada.

Sunarto. 2004. Akuntansi Manajemen. Yogyakarta: AMUS Yogyakarta.

Swastha, Basu. 2005. Manajemen Pemasaran Modern. Yogyakarta: Liberty.

Sylvia, Rika. 2018. "Analisis Perhitungan Harga Pokok Produksi Dengan Menggunakan Metode Full Costing Dan Variabel Costing Pada Tahu Mama Kokom Kotabaru". JEM: Jurnal Ekonomi Dan Manajemen 12 (1): 53-59.

Tjiptono, Fandy. 1997. Strategi Pemasaran. Yogyakarta: Andi.

Widati, Sri and Purwadarminta. 2002. Tenun Nusantara. Klaten : Primada Karya.

Widodo, Eko. 2013. Akuntansi Manajemen. Jakarta: Salemba Empat. 